\title{
Study on enterprise VAT planning under the policy of "camp changed to increase"
}

\author{
Shuying Du ${ }^{1}$ \\ ${ }^{1}$ Shandongyingcai University, Shan Dong, Ji Nan, 250104
}

Key words: "Camp changed to increase"; value-added tax; planning

\begin{abstract}
In order to solve the problem of double taxation of the tax in the process of our country and continue to improve and perfect the tax system of our country, "replacing business tax with value-added tax(VAT) policy came into being, but combined with the actual situation of our country and the current" replacing business tax with value-added tax(VAT) "policy just trial, still have a lot to optimize and perfect place. At present, some enterprises even there is no reduction in tax burden, but increased phenomenon. So now, how to make use of scientific tax planning to realize tax reduction, negative reduction and financial risk becomes very important. This article will explore how to carry out scientific and reasonable value-added tax planning.
\end{abstract}

\section{Introduction}

At present, our country is in the rapid development of the market economy period, before the tax policy, because of its defects gradually, has been unable to meet the needs of China's economic development and structural adjustment, and even play a negative role. Because the tax revenue of our country has been the existence of double taxation, and taxation system vulnerabilities and other issues, to solve these problems, China has proposed and implemented the policy of replacing business tax with value-added tax(VAT), at present, China changed to increase the implementation of the policy is not a long time, just at the initial stage, replacing business tax with value-added tax(VAT) policy still has many loopholes need to improve tax planning, enterprises should use effective strategies.

\section{The camp changed to increase the impact of policies on Enterprises}

To understand the effect of replacing business tax with value-added tax(VAT) "policy on the enterprise, we must first understand that business tax is tax levied according to the turnover and the provisions of the tax and value-added tax; and, in part based on value-added tax.

Camp changed to increase policy has a great impact on China's enterprises. On the one hand, for some enterprises, business tax reform for value-added tax is to reduce the negative tax and cost, thereby increasing profits. On the other hand, the business tax reform value-added tax is mainly to avoid repeated tax collection of large problems, to a large extent, reduce the cost of enterprises, so that enterprises in the reasonable range, minimize the loss of interest. Camp changed to increase the impact of different policies on enterprises as follows:

Before the value-added tax policy has not been implemented, the tax policy that has been used and implemented in our country is a business tax policy. The requirement of this tax system is that the enterprise must pay the full amount of the tax revenue, and there is no deduction. Because of the nature of this system, the current service industry in our country is developing backward and inflexible, and it is difficult to see better prospects for development. However, the tax policy to promote replacing business tax with value-added tax(VAT), largely for the service industry to solve the problem, because the implementation of the policy of replacing business tax with value-added tax(VAT) mainly can avoid repeated tax problems, this would greatly help the service industry to reduce the economic burden, can improve the efficiency of work, can eventually improve in profit profitability and so on. According to the relevant services sector, we can easily find that the camp changed to increase policy is an important tool for the development of enterprises to reduce burdens. Enterprises are profitable for the purpose of production and management, and enhance turnover is 
an important pursuit of enterprise development, and if enterprises can not reach profitability, then eventually bankruptcy or even bankruptcy. Camp changed to increase policy, by reducing the negative tax pressure on enterprises, can effectively enhance the profitability of enterprises. In the process of China's economic development, the role of the increase of the camp can not be ignored[1].

\section{"Battalion changed to increase" under the enterprise tax planning necessity}

A part of China and some provinces in the industry enterprises to conduct a pilot operation of replacing business tax with value-added tax(VAT) "policy, in the pilot application, based on the deployment and implementation of the plan, the implementation of the business tax system of our country industry has gradually changed into the implementation of value-added tax system. In the implementation of the "camp to change" system, enterprises will put forward and implement a number of tax policies associated with the implementation of the program. However, after the implementation of the "camp changed to increase" system, enterprises will have some changes in their identity, therefore, the strict performance of tax according to law can reduce the risk of tax related. Enterprises should strictly comply with the tax law for tax payment, and the person in charge of tax needs to have a comprehensive and detailed understanding and grasp of the tax policy. However, we know that in reality, there are many taxpayers who have no knowledge and ability in a short period of time to understand and grasp and can be implemented by replacing business tax with value-added tax(VAT) "policy and can correctly complete the relevant procedures and processes, tax returns this result, in many enterprises of our country will follow the national tax law strictly to make input tax deduction, invoices or even cannot be issued a formal specification of the value-added tax, even not on time is not timely pay tax on enterprises to actively improve the corresponding tax obligation etc.. Although this behavior is not an enterprise deliberately take illegal means, tax evasion or deferred tax, but the tax risk will affect the incidence, and increased risk, which will affect the business. "Replacing business tax with value-added tax(VAT)" system implementation requires enterprises in a short period of time, reasonable planning of the tax, but also requires companies to strengthen the relevant financial personnel and accounting personnel training, so that these staff can quickly understand and grasp the current value-added tax, value-added tax system and according to the standard. Set the record books and tax, enterprises should strengthen the relevant personnel "replacing business tax with value-added tax(VAT)" policy and a series of related policies and specific procedures for tax declaration of awareness and understanding, to the staff to be able to accurately fill out the tax declaration form, and constantly improve and enhance their ability and level of value added tax. In addition, enterprises should also participate in, as well as organize some tax activities[2].

The establishment and implementation of the "replacing business tax with value-added tax(VAT) tax reform in China, the original VAT general taxpayer, the tax burden from his overall view is declining, because the original payment of value-added tax, enterprises in the implementation of" replacing business tax with value-added tax(VAT) "system before, enterprises may purchase many different types of business tax service in practice but also can only obtain the business tax invoice, and income tax is not deductible for. But after the implementation of "replacing business tax with value-added tax(VAT)" system, the original VAT taxpayer, invoices can also obtain VAT, which can deduct input tax, the result is his negative tax is declining. However, the tax rate is still rising for the average taxpayer who has changed the camp to increase. The reason for this situation is that VAT is the implementation of input tax deduction system, which can be deducted from the income directly affect the "camp changed to increase" ordinary taxpayers negative corporate tax value. According to the relevant research results, some enterprises negative tax rise is particularly evident, such as the transportation industry general taxpayer enterprises, because the transportation industry in the "replacing business tax with value-added tax(VAT)" system has been purchased and reserve transport tools and equipment, therefore, the current can be deducted the amount is a bit small, in addition, the highway toll cannot get VAT invoice or just use the gas station to the ordinary invoice. In addition, many other sectors of the "camp changed to increase" general taxpayer enterprises also 
exist this deduction is relatively small, so eventually lead to negative tax rise. However, some small-scale tax enterprises are levied on VAT according to the rate of collection of $3 \%$, which is compared with the implementation of the "camp changed to increase" system. And their tax rate is reduced, at the same time, the value-added tax as a foreign tax, business tax and conversion, according to the situation of negative tax will decline. In short, as the implementation of the general corporate tax replacing business tax with value-added tax(VAT) "system, their negative tax is rising, and this has led to the enterprise tax planning initiative, based on the business activities of enterprises and tax conduct adjustment and arrangement, eventually reducing the tax burden[3].

\section{"Battalion changed to increase" under the enterprise tax planning measures}

In order to promote and carry out "replacing business tax with value-added tax(VAT) tax reform, countries have also introduced some" replacing business tax with value-added tax(VAT) "relevant supporting measures and transitional financial support policies, hoping it can effectively alleviate the" replacing business tax with value-added tax(VAT) tax implementation and negative tax volatility implementation brings to the enterprise and negative influence. At the same time, "camp changed to increase" tax policy, has been a lot of pilot areas of recognition and support, many regions also for "camp changed to increase" system of better implementation, put forward a lot of preferential policies. For some of the economic situation is not very good, the economic environment is not too bad, or even more serious is the increase of the tax burden of enterprise and industry, the central government departments in our country are put forward to provide appropriate subsidies to the financial enterprises, these enterprises and industry reasonable tax burden reduce is appropriate. The central government department not only provide financial subsidies, but also according to the specific conditions of enterprises and industries that meet economic difficulties, particularly proposed and formulated a series of targeted and implementation of support policies. With the development of economic policy, it is not difficult to understand that the central government department in recent years, for replacing business tax with value-added tax(VAT) tax system implementation and implementation has been formulated and issued a new policy suitable to support, bring new tax system to solve the problems, and gradually perfecting the tax system reform. In the face of some of the Central Treasury's proposed preferential policies, enterprise accounting and accounting personnel must know how to use reasonable full, timely and reasonable, and in accordance with the provisions of the articles of association be financial subsidies to the relevant departments of the application, at the same time, the financial staff should carefully study and in-depth analysis of the state the policy document, ability to constantly improve the enterprise tax planning. Enterprises should understand the scientific application of preferential policies[4].

Because of the different demands of taxpayers, our country's taxpayers are also separated from each other. In spite of the classification, there will be a lot of difference, but in general, the taxpayer is the tax classification standard of economic ability and level of enterprise funds in addition to taxpayers and other factors are classified in accordance with the above criteria, our country taxpayer generally divided into two types, one is the general taxpayer, another is the small scale taxpayer. From the name we can see, the so-called small-scale taxpayers, refers to because of their economic capacity is limited, resulting in the lower rate of the crowd, they need to be turned over to the tax, is only a small part of my salary amount, small scale taxpayer, is a subject to reduce the corporate tax the tax burden, but also conducive to the development of enterprises better and more long-term. Correspondingly, the average taxpayer. Compared with small-scale taxpayers, the tax rate applicable to the average taxpayer is relatively high, and the pressure on such enterprises is relatively large, because they may increase tax payments at any time. Therefore, the relevant personnel in charge of the enterprise financial management, must comply with the provisions of the relevant national policies, prudent and reasonable choice of appropriate taxpayer, should pay special attention to the effect of the taxpayer's choice of enterprise development.

Because of the different status of taxpayers, the planning of purchasing business will also be different. First of all, as small-scale taxpayers, because of the small scale taxpayers usually pay taxes in accordance with the lower tax rate multiplied by the sales of the algorithm, but the input 
models which is not deductible, therefore, in the face of the quality difference is not large commodity, buyers can according to the actual situation as much as possible with the suppliers to lower prices; however, as the general taxpayer, because the general taxpayer can deduct input funds, which, if not too big difference in price and quality products, according to the actual situation as far as possible to choose to cooperate with the same general taxpayer identity provider, then the general taxpayer can also maximize the input section of the deductible.

The planning of enterprise sales can start in three directions. The first is the service outsourcing enterprise production planning, related development in the pilot areas to better enjoy "replacing business tax with value-added tax(VAT)" system brings benefits and benefits, can cooperate with labor through the way of outsourcing and the pilot areas, and the enterprise can be the tax deduction, and tax on enterprises to optimize the scientific and reasonable; second is the settlement planning, enterprises can use reasonable way will be a one-time tax burden shared by many times, so as to reduce the pressure of the enterprise, such as the use of payment methods, or by way of commission, a one-time payment of the pressure gradually dispersed, even as savings stage storage and value-added, and to promote the enterprise funds through the way of liquidity and efficiency; and Is the business model of planning, because of different operating modes for different enterprises in different industries and in the same industry, national tax departments will formulate and implement different tax policies, therefore, enterprises should learn to make appropriate adjustments to the reasonable operation mode, in order to reduce the tax amount and tax pressure. Although because of the different industry, different business models, countries have different tax standards, but the enterprise can not blindly pursue policies, thus affecting the proper deployment of the direction of enterprise, adjust the business model must be realistic, according to local conditions[4].

According to the declaration of the different ways, enterprises can also work on tax planning, at present our country enterprise tax declaration in two ways, one is combined with another declaration is their declaration, enterprises in the selection and determine the specific tax declaration before, enterprises must understand and according to the relevant provisions of the policy science, calculate two kinds of methods of reporting the taxes paid by how much is. Through the direct comparison of taxes, enterprises can make reasonable choices naturally.

\section{Epilogue}

With the rapid development of China's economy, China's tax policy has also undergone tremendous adjustments and changes. Because of the globalization of the world economy, China's traditional tax policy can not meet the needs of China's current economic development. China's policy of levying VAT from the business tax reform is to meet the needs of the current economic development of our country, and it also helps to optimize and upgrade the industrial structure of our country. The promotion and development of the policy of "camp change to increase" has a distinct function, that is, it can solve the problem of repeated taxation. But because of replacing business tax with value-added tax(VAT) policy implementation is not a long time, in the process of the implementation of the system also exposed some problems, the camp changed to increase policy brings to different companies vary, such as some enterprises in the implementation of the policy of replacing business tax with value-added tax(VAT), but increase the negative tax; and some enterprises really changed by policy in the camp, and reduce the negative tax cost, improve profits; therefore, enterprises in the implementation of the national tax policy to comply with and at the same time, according to their own development, the use of reasonable measures for tax planning.

\section{References:}

[1]Yang L. Influence of Camp Changed to Increase Cost of Project[J]. Building Technology Development, 2016.

[2]Ma L, Zhang X, Wang S. Research on the Practical Operation Specification of Accounting Treatment of Pilot Enterprises Business Tax Changing to VAT[J]. Open Journal of Social Sciences, 
2015, 03(5):95-102.

[3]Yin R. Study on the Problem of China' s Business Tax Changes to VAT-Based on the Panel Data of Listed Companies in the Transport Industry[J]. Open Journal of Social Sciences, 2015, 03(11):157-164.

[4]Meijer P C, Verloop N, Beijaard D. Multi-Method Triangulation in a Qualitative Study on Teachers' Practical Knowledge: An Attempt to Increase Internal Validity[J]. Quality \& Quantity, 2002, 36(2):145-167. 